DOI 10.22460/infinity.v7i2.p155-164

\title{
STUDENTS' MATHEMATICAL REPRESENTATION ABILITY THROUGH IMPLEMENTATION OF MAPLE
}

\author{
Lusiana $^{1}$, Yunika Lestaria Ningsih ${ }^{2}$ \\ 1,2 Universitas PGRI Palembang, Jl. Jend A. Yani Lorong Gotong Royong No. 9/10 Ulu, Palembang, \\ South Sumatera, Indonesia \\ ${ }^{1}$ luu_sii_ana@gmail.com, ${ }^{2}$ yunika.pgri@gmail.com
}

Received: June 25, 2018 ; Accepted: August 31, 2018

\begin{abstract}
This research aims to investigate the students' mathematical representation ability through the implementation of Maple in learning definite integral and those with ordinary learning. This research used a quasi-experimental design with a pretest-posttest control group design. The population of this study was students of $2^{\text {nd }}$ semester of Mathematics Education Program at PGRI Palembang University Academic year 2017/2018. The sample in this study were students of class II.A and II.B, class II.A as a control group and class II.B as experiment group. Data were collected through a test of mathematical representation ability. Data in this study were analyzed through descriptive quantitative. The result of this study showed that students' mathematical representation ability through implementation Maple in learning definite integral better than those who get the ordinary learning.
\end{abstract}

Keywords: Definite Integral, Students' Mathematical Representation Ability, Maple.

\begin{abstract}
Abstrak
Tujuan penelitian ini adalah untuk mengetahui perbedaan kemampuan representasi matematis antara mahasiswa yang mendapatkan pembelajaran berbantuan Maple pada topik integral tentu dengan mahasiswa yang mendapat pembelajaran biasa. Penelitian ini menggunakan metode quasi eksperimen dengan desain pretest-posttest control-group design. Populasi dalam penelitian ini terdiri dari mahasiswa semester II Program Studi Pendidikan Matematika Universitas PGRI Palembang Tahun Akademik 2017/2018. Sampel dalam penelitian ini adalah mahasiswa semester II.A dan II.B, dengan kelas II.A sebagai kelas kontrol dan kelas II.B sebagai kelas eksperimen. Data dikumpulkan melalui tes kemampuan representasi matematis. Analisis data dilakukan dengan deskriptif kuantitatif. Hasil analisis data menunjukkan bahwa kemampuan representasi matematis mahasiswa melalui pembelajaran berbantuan Maple lebih baik dari mahasiswa yang mendapat pembelajaran biasa.
\end{abstract}

Kata Kunci: Integral Tentu, Kemampuan Representasi Matematis, Maple.

How to Cite: Lusiana, L., \& Ningsih, Y. L. (2018). Students' Mathematical Representation Ability through Implementation of Maple. Infinity, 7(2), 155-164. doi:10.22460/infinity.v7i2.p155-164. 


\section{INTRODUCTION}

Integral calculus is a subject which should be taken by students of mathematics education on the early semester. Integral is a part of calculus concept that is important to be understood by students (Serhan, 2015). According to Oberg (2000) student's understanding on this topic determines student understands figure in advanced mathematics problems out that involves integral in it such as advanced calculus, differential equation, and so on. Furthermore, in learning Integral most of students can do a calculation of integral procedurally, but they experience the trouble of settling integral issue conceptually and an implementation of definite integral (Oberg, 2000).

Besides that, the trouble and weakness of students' in learning integral were students difficult to determine upper limit and lower limit of an integral (Nursyahidah \& Albab, 2017), students confused in answering the integral exercise (Yuliana, Tasari \& Wijayanti, 2017), students are not able to implement mathematical representation on definite integral topic (Gonzales-Martin \& Camacho, 2004), and students didn't understand with symbolic and verbal definitions of definite integral (Grundmeier, Hansen, \& Sousa, 2006; Serhan 2015).

According to student's analysis in definite integral topic which had been expressed, generally it can be argued that the student's difficulty in learning the definite integral concept is related to mathematical representation ability. Goldin (Rangkuti, 2014) said, "Representation is a configuration (format or arrangement) which is able to describe, represent, and symbolize something in one way." Kinds of representations are often used in describing mathematics ideas such as diagram, graph, table, mathematical statement, written text, or even combination of those (Hutagaol, 2013).

Mathematical representation ability is an ability which is expected to be reachable in mathematics learning. NCTM stated there are five abilities which are aim in this mathematics learning, those are problem-solving, reasoning, communication, connection and representation (Hutagaol, 2013). Mathematical representation ability is considered crucial, because it's closely connected to communication ability and mathematical problem-solving (Sabirin, 2014). Mathematics concept representations in kinds of formats are used by someone in communicating the understood mathematics concept. In solving mathematical problem, mathematical representation, including picture and table would be able to help anyone who simplifies mathematical problem formerly was considered difficult.

Therefore, it is an important to analyze the mathematical representation ability of students when they learning the definite integral. According to Serhan (2015) students must developed their ability to make connections between different representations. The students' ability in make more than one representations of the definite integral concept, show the students understanding of it. In additional, Huang (2015) stated that the concept of integrals can be presented in different representation. The graphical representation is used to solve the large area under a curve, and symbolic representation is used to solve the integration problem.

Many studies were aimed to overcome the student's weaknesses in understanding integral. Tall (1993) expressed that computer program can be used to help student in understanding calculus concept. I additional, NCTM stated that students can explore and identify the concepts in mathematics and its relation using computer technology (Ningsih \& Paradesa, 2018). One of software which is able to be used for helping a learning of integral calculus is Maple. Maple is software that was developed by Waterloo Maple Inc to solve mathematics 
problem. According to Garvan (2001), maple program has such a great potential that is useful in mathematics learning both at school and college. This program had been being used by many students, educators, mathematicians, statisticians, and scientists to do numeric and symbolic computation.

As for the advantages of maple program was mentioned by Garvan (2001) such as : (1) can do numeric computation exactly, (2) can do numeric computation for such a big number, (3) can do symbolic computation well, (4) has a plethora of default instruction in library and packages to mathematics processing widely, (5) has plot facility and animation for chart both in twodimensional (2D) and three-dimensional (3D), and (6) has programming language facility which can be used to write function, package, interactive window, etc.

Based on a study which had been established, using of maple in mathematics learning was proven able to give lots of benefits. The development of teaching materials in integral calculus maple-based that was established by Paradesa, Zulkardi \& Darmawijoyo (2013) has potential effect towards student's ability of understanding in mathematical concept. Maple integrating on integral calculus can enhance student's mathematical concept understanding ability (Awang \& Zakaria, 2013; Ningsih \& Paradesa, 2018). Maple which had been used as medium of calculus vector was successful in enhancing student's understanding abiliy (Noor et al., 2018).

Considering the advantages of using maple in learning, this study will investigate the implementation of it towards the students' mathematical representations ability. Therefore, the hypothesis of this study is "students' mathematical representation ability through implementation maple better than those who get the ordinary learning". This study limited on definite integral topic. The mathematical representation ability that was reviewed on this study is limited on three indicators, which are (1) visual representation: students can serve data or information from a representation into chart, (2) symbol representation or mathematical expression, students can write mathematics model or mathematics formula, and (3) verbal representation: students can give the explanation about steps of problem solving.

\section{METHOD}

This study used quasi-experimental design with pretest-posttest control-group design. The population of this study was students of $2^{\text {nd }}$ semester of Mathematics Education Program at Universitas PGRI Palembang in aacademic year 2017/2018. Sample in this study were students of class II.A and II.B, class II.A as control group (CG) with 42 students, and class II.B as experiment group (EG) with 42 students. Students in EG get the implementation of maple, meanwhile the CG get the ordinary learning.

Data were collected through the essay test of mathematical representation ability. This test is including 3 (three) problems which containing the 3 (three) indicators of mathematical representation ability. Example of the test, can be seen in Figure 1. 
Misalkan diketahui suatu bidang datar dibatasi oleh $y=-x+2, y=x^{2}, x=-4$, dan $x=2$.

a. Buatlah grafik bidang datar tersebut.

b. Tuliskan rumus untuk menentukan luas bidang datar tersebut

c. Tentukan luas bidang datar tersebut, lengkapi dengan penjelasan dari langkahlangkah yang dilakukan.

Let the area under the curves, $y=-x+2, y=x^{2}, x=-4$, and $x=2$

a. Sketch the graph of the area

b. What is the formula to calculate large of the area

c. Find the large of area, and give the explanation

Figure 1. The example of test

Point a) is indicator the visual representation, students have to sketch the graph based on the function correctly. Point b) is problem for symbol representation or mathematical expression; students should make a formula to determine the large of the area. The last point is indicator the verbal representation, students have to explain by their own words how to find the large of area. The maximum score for each indicator is 4 and the lowest is 0 .

Before conducting the research, two groups had been ensured that they had similar capability in mathematical representation. It was measured with homogeneity variants of pretest. Then, data of students' mathematical representation ability posttest were analyzed through descriptive quantitative. The normality and homogeneity test was conducted as the prerequisite test for inference statistic. The normality test use Kolmogorov-Smirnov method, and Lavene method use for the homogeneity test.

\section{RESULTS AND DISCUSSION}

\section{Results}

This study was established on Month February-April, 2018. Definite integral material in this study is limited on definite integral topic, the large of area and the volume of rotary objects. The result of students' mathematical representation ability pretest can be seen on Table 1 .

Table 1. The Result of Pretest

\begin{tabular}{ccc}
\hline & EG & CG \\
\hline \hline $\bar{x}$ & 22.02 & 20.91 \\
$S$ & 5.81 & 6.42 \\
Max & 31.25 & 40.63 \\
Min & 6.25 & 9.38 \\
\hline \hline
\end{tabular}

According to Table 1, known that average of pretest score of students' mathematical representation ability between EG and CG is not too different. The result of pretest homogeneity can be seen in Table 3. EG and CG have homogeneous variants. It means that two groups have the same initial of students' mathematical representation ability. 
Table 2. The Result of Homogeneity Pretest

\begin{tabular}{|c|c|c|c|c|}
\hline Groups & $\mathbf{N}$ & $\mathbf{F}$ & Sig & Conclusion \\
\hline EG & 42 & \multirow{2}{*}{0.462} & \multirow{2}{*}{0.499} & \multirow{2}{*}{ Homogeneous } \\
\hline $\mathrm{CG}$ & 42 & & & \\
\hline
\end{tabular}

After the learning was held, two groups took the posttest. The result of posttest is described on Table 3. Based on Table 3, known that the average posttest score of students' mathematical representation ability in EG is 54.76 higher than the CG score.

Table 3. The result of Postest

\begin{tabular}{ccc}
\hline & EG & CG \\
\hline $\bar{x}$ & 54.76 & 35.12 \\
$S$ & 10.03 & 9.33 \\
Max & 84.38 & 65.62 \\
Min & 34.38 & 15.62 \\
\hline
\end{tabular}

The result of normality and homogeneity of posttest as the prerequisite test can be seen on Table 4 and Table 5.

Table 4. The Result of Normality Test

\begin{tabular}{ccccc}
\hline Groups & N & K-S & Sig & Conclusion \\
\hline EG & 42 & 0.699 & 0.714 & Normal \\
CG & 42 & 1.200 & 0.112 & Normal \\
\hline
\end{tabular}

Table 5. The Result of Homogeneity Test

\begin{tabular}{|c|c|c|c|c|}
\hline Groups & $\mathbf{N}$ & $\mathbf{F}$ & Sig & Conclusion \\
\hline EG & 42 & \multirow{2}{*}{0.504} & \multirow{2}{*}{0.480} & \multirow{2}{*}{ Homogeneous } \\
\hline $\mathrm{CG}$ & 42 & & & \\
\hline
\end{tabular}

Based on the normality test, data of students' posttest are in normal distribution. Therefore, data testing is continued with variants homogeneity by using Lavene Test. Based on Table 5, the significant score was 0.480 which means higher than 0.05 so that posttest data variants on EG and CG are homogeneous.

Hypothesis testing for normal and homogeneous data of students' mathematical representation ability are continued by doing $t$ test. As for the tested-hypothesis in this study is students' mathematical representation ability that got implementation of Maple learning is better than those who got ordinary learning. The result of $t$ test can be seen on Table 6 .

Table 6. The Result of Average Differences Test

\begin{tabular}{|c|c|c|c|c|}
\hline Groups & $\mathbf{N}$ & $T$ & Sig & Conclusion \\
\hline $\mathrm{EG}$ & 42 & \multirow{2}{*}{9.291} & \multirow{2}{*}{0.000} & \multirow{2}{*}{ Different } \\
\hline $\mathrm{CG}$ & 42 & & & \\
\hline
\end{tabular}

Based on Table 6 shows the significant score of $t$ test is 0.000 , this score is lower than 0.05 which causes the research hypothesis of this study is acceptable. In other words, it shows that 
students' mathematical representation ability that got implementation of Maple learning on EG is better than those who got ordinary learning on CG.

According to the analysis result of students' response on posttest, students' mathematical representation ability for each indicator can be seen on Table 7.

Table 7. Average Score of Students' Mathematical Representation Ability Indicator on EG

\begin{tabular}{clc}
\hline No & \multicolumn{1}{c}{ Measured Aspects } & Average Score \\
\hline 1 & $\begin{array}{l}\text { Visual Representation : } \\
\text { serve data and information from a representation } \\
\text { into graphical representation }\end{array}$ & 61.01 \\
\hline 2 & $\begin{array}{l}\text { Symbol Representation or Mathematical } \\
\text { Expression : } \\
\text { a. build mathematics model } \\
\text { b. write the mathematics formula }\end{array}$ & 30.36 \\
\hline 3 & $\begin{array}{l}\text { Verbal Representation : } \\
\text { write an explanation about steps of problem- }\end{array}$ & 60.42 \\
& solving & 54.96 \\
\hline
\end{tabular}

Table 7 shows that indicator which experiences the highest score is indicator 1, which the visual representation ability. On the contrary, indicator which experiences low score is indicator 2. In indicator symbolic representation, students are not able to make mathematical model correctly. The average score is only 30.36 .

\section{Discussion}

The result of this study showed that students' mathematical representation ability through implementation of Maple in learning definite integral topic is better than those who got ordinary learning. Maple using in integral calculus learning gives a plethora of benefits on students. The advantage of maple in making graph helps them to make a correct graph and understand it. Besides, three-dimensional animation graph in Maple makes students more understand the volume of rotary objects, so that the right method can be applied in figuring problems out.

For example on indicator 1, students have to make a representation into a graph correctly. Pretest result shows that students are still not good enough at making graph of the large area on flat field that is limited by two curves. The mistakes that had been done by students on this indicator are, they cannot determine the right coordinate-point, they cannot determine cuttingpoint of two curves, and they cannot determine the upper and lower limit of an integral. This agrees with the finding of previous research study (Nusyahidah \& Albab, 2017). The example of students' response can be seen on this Figure 2. 


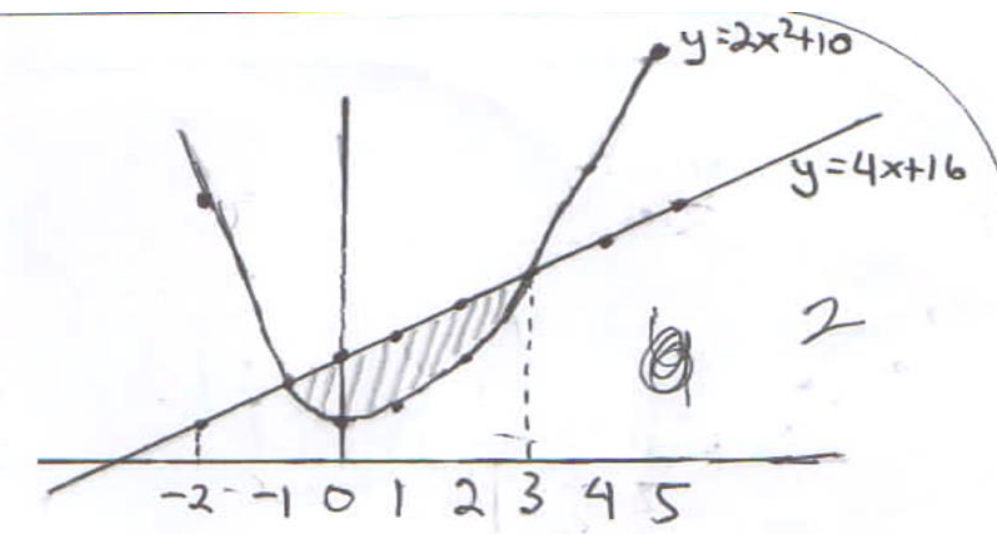

Figure 2. Students' EG response on pretest

Then, after the implementation of Maple was applied, students' response to this indicator increases. They're already able to make graph well, determine cutting-point of two curves appropriately, and able to determine the upper and lower limit of integral. The example of students' response can be seen on this Figure 3. This finding show that students visual representation in make graph is increased. Students are more attractive and supported to make the correct graph with Maple. This condition is in line with the statement of previous research studies (Kilicman, Hassan \& Husain, 2010; Ningsih \& Paradesa, 2018).

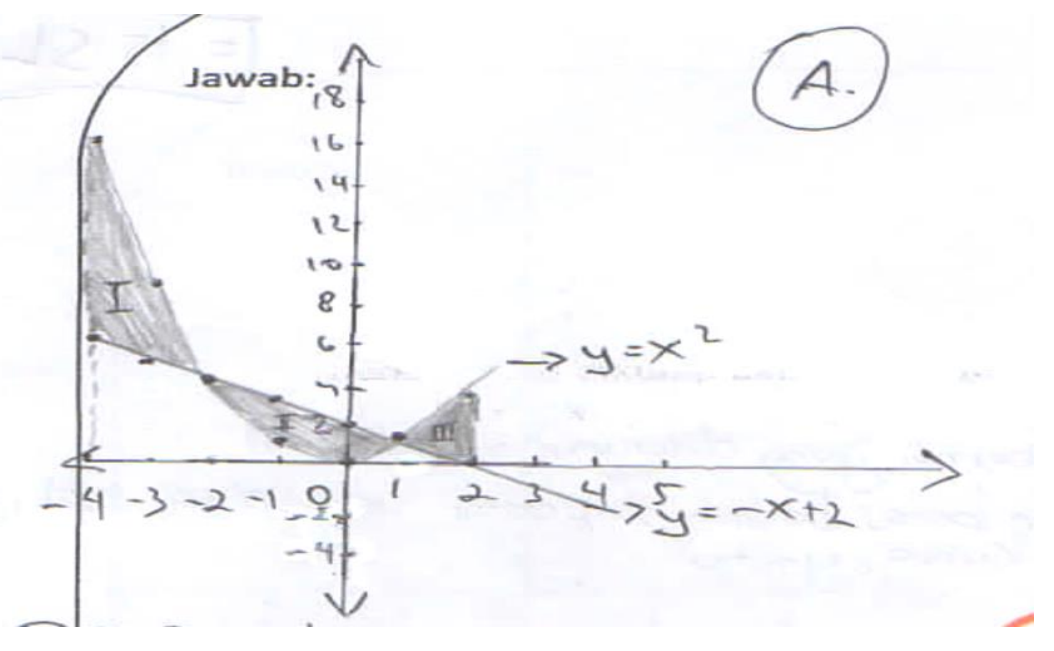

Figure 3. Students' EG response on posttest

Meanwhile, for indicator 2, part a) students are able to make the correct formula for finding the large area. The average score is 60.42 . Students seem like to solve the problem based on the formula that had been given. This fact shows that students were tends to solve the problem using the analytical thinking (Huang, 2015). For indicator 2, part b) students are not able to make the correct mathematical model. Students felt difficult to understanding the mathematics symbols in learning integral, as stated by Grundmeier, Hansen \& Sousa (2006). In indicator 3 , students are not able to make the explanation of the problem solving based on their own words. Students felt difficult in describe their answer; many of them just calculated the integral not give the way to find the answer. This difficulty is also similar with Serhan (2015). 


\section{CONCLUSION}

Based on the result of data analysis, it can be concluded students' mathematical representation ability through the implementation of maple in learning definite integral topic is better than those who got ordinary learning. The average score of students' mathematical representation ability on Experiment-Group (EG) is 54.76 higher than Control-Group (CG).

The average score of students mathematical representation ability in this study is still have to be increased. Based on findings, students are able to make a graph representation, even though the score is not big enough. In the future study this ability is still need to be developed. Additionally, in this study, students still have so much weakness when they tried to build mathematical model from real life issues for definite integral topic and to give the explanation. The upcoming study will analyze how to make that ability better.

\section{ACKNOWLEDGMENTS}

This study is funded by Universitas PGRI Palembang, under DIPA Penelitian LPPKMK in academic year 2017/2018. Researchers would like to thank to Rector Universitas PGRI Palembang, Dean of FKIP Universitas PGRI Palembang, lecturers, and students who are involved in this project.

\section{REFERENCES}

Awang, T. S., \& Zakaria, E. (2013). Enhancing students' understanding in integral calculus through the integration of Maple in learning. Procedia-Social and Behavioral Sciences, 102, 204-211.

Garvan, F. (2001). The Maple book. New York. Retrieved from https://books.google.com/books?id=5x7NBQAAQBAJ

González-Martín, A. S., \& Camacho, M. (2004). What is first-year Mathematics students' actual knowledge about improper integrals?. International journal of mathematical education in science and technology, 35(1), 73-89.

Grundmeier, T. A., Hansen, J., \& Sousa, E. (2006). An exploration of definition and procedural fluency in integral calculus. Problems, Resources, and Issues in Mathematics Undergraduate Studies, 16(2), 178-191.

Huang, C. H. (2015). Calculus Students' Visual Thinking of Definite Integral. American Journal of Educational Research, 3(4), 476-482.

Hutagaol, K. (2013). Pembelajaran kontekstual untuk meningkatkan kemampuan representasi matematis siswa sekolah menengah pertama. Infinity Journal, 2(1), 85-99.

Kilicman, A., Hassan, M. A., \& Husain, S. S. (2010). Teaching and learning using mathematics software "The New Challenge". Procedia-Social and Behavioral Sciences, 8, 613-619.

Ningsih, Y. L., \& Paradesa, R. (2018). Improving students' understanding of mathematical concept using maple. Journal of Physics: Conference Series, 948(1), 012034. 
Noor, N. M., Sulaiman, H., Alwadood, Z., Halim, S. A., Wahid, N. F. S., \& Ab Halim, N. A. (2018). Development of Learning Tools using Maples for Engineering Mathematics Subject. Indonesian Journal of Electrical Engineering and Computer Science, 9(1), 131-138.

Nursyahidah, F., \& Albab, I. U. (2017). Investigating student difficulties on integral calculus based on critical thinking aspects. Jurnal Riset Pendidikan Matematika, 4(2), 211-218.

Oberg, T. D. (2000). An investigation of undergraduate calculus students ' conceptual understanding of the definite integral. Retrieved from https://scholarworks.umt.edu/cgi/viewcontent.cgi?referer=\&httpsredir=1\&article=116 $51 \&$ context $=$ etd

Paradesa, R., Zulkardi, Z., \& Darmawijoyo, D. (2013). Bahan Ajar Kalkulus 2 Menggunakan Macromedia Flash Dan Maple Di Stkip Pgri Lubuklinggau. Jurnal Pendidikan Matematika, 4(1), 95-109.

Rangkuti, A. N. (2014). Representasi matematis. Forum Paedagogik, 6(1), 110-127.

Sabirin, M. (2014). Representasi dalam pembelajaran matematika. Jurnal Pendidikan Matematika UIN Antasari, 1(2), 33-44.

Serhan, D. (2015). Students' Understanding of the Definite Integral Concept. International Journal of Research in Education and Science, 1(1), 84-88.

Tall, D. (1993). Students' difficulties in calculus. In proceedings of working group, 3, 13-28.

Yuliana, Y., Tasari, T., \& Wijayanti, S. (2017). The Effectiveness Of Guided Discovery Learning To Teach Integral Calculus For The Mathematics Students Of Mathematics Education Widya Dharma University. Infinity Journal, 6(1), 01-10. 
164 Lusiana \& Ningsih, Students' Mathematical Representation Ability through ... 